\title{
JUDUL SYAIR KOMPOSISI PURNOMO
}

\section{Muhammad Kholqin Jadid}

Universitas Nahdlatul Ulama Sidoarjo

\section{PENGANTAR}

Puisi sebagai genre sastra yang dihargai sebagai ekspresi keindahan, atau perasaan artistik melalui kata dalam bentuk sajak atau prosa . Tema sentral puisi telah berubah seiring waktu; pada jaman dahulu, puisi-puisi itu diorientasikan untuk menceritakan eksploitasi dan prestasi para pejuang dalam pertempuran. Sementara di abad pertengahan, puisi romantis mendapatkan lebih banyak relevansi. Saat ini, puisi romantis masih ada di atas meja, namun tema inspirasi lain telah muncul, seperti hak asasi manusia dan lingkungan. Ini jelas mencerminkan bahwa literatur beradaptasi dengan waktu di mana mereka yang menggunakan jenis seni ini hidup untuk mengekspresikan diri (Conceptodefinicion, 2019). 
Puisi adalah jenis literatur berdasarkan interaksi kata dan ritme. Ini sering menggunakan sajak dan meter (seperangkat aturan yang mengatur jumlah dan pengaturan suku kata di setiap baris). Dalam puisi, kata-kata dirangkai untuk membentuk suara, gambar, dan gagasan yang mungkin terlalu rumit atau abstrak untuk diuraikan secara langsung (Literary Terms, 2019).

Puisi adalah jenis seni yang memungkinkan penulis untuk menggunakan imajinasi dan kreativitas mereka yang tidak diizinkan oleh bentuk sastra lain. Anda diberi berbagai teknik dan gaya yang jauh lebih luas, dan elemen-elemen untuk dikerjakan. Namun, Anda harus menggunakannya dengan hati-hati, unik, dan bijak. Ini adalah perbuatan yang sulit untuk dilakukan, tetapi juga merupakan favorit di antara banyak seniman. Banyak penulis menganggap puisi sebagai bentuk sastra paling sulit namun paling memuaskan. Dan memang demikian. Jumlah elemen, teknik, dan kreativitas tidak terjawab di dunia prosa (Hess, 2019). 


\section{SANG PENYAIR}

Tulisan ini mengulas goresan penyair bernama lengkap Agung Purnomo dan tumbuh di Sidoarjo. Berikut tulisan syair beliau telah disebarkan secara luas melalui penerbit nasional, yaitu: STIEBA Madura Press, dan UNUSIDA Press.

Tabel 1. Syair Karya Kreasi Agung Purnomo

\begin{tabular}{|c|c|c|c|c|c|c|}
\hline No & $\begin{array}{l}\text { Judul } \\
\text { Puisi }\end{array}$ & $\begin{array}{l}\text { Jenis } \\
\text { puisi }\end{array}$ & $\begin{array}{l}\text { Judul } \\
\text { buku }\end{array}$ & Penulis & Tahun & Penerbit \\
\hline 1 & $\begin{array}{l}\text { Rindu di } \\
\text { Ubun- } \\
\text { Ubun }\end{array}$ & $\begin{array}{l}\text { Puisi } \\
\text { Bebas }\end{array}$ & $\begin{array}{c}\text { Rassana } \\
\text { Jlantir }\end{array}$ & $\begin{array}{c}\text { Agung } \\
\text { Purnomo }\end{array}$ & 2019 & $\begin{array}{c}\text { STIEBA } \\
\text { Madura } \\
\text { Press }\end{array}$ \\
\hline 2 & Pandai & $\begin{array}{c}\text { Puisi } \\
\text { Riddle }\end{array}$ & $\begin{array}{c}\text { Tolesan } \\
\text { Aditi } \\
\end{array}$ & $\begin{array}{c}\text { Agung } \\
\text { Purnomo, } \\
\text { Nur Asitah } \\
\end{array}$ & 2019 & $\begin{array}{c}\text { STIEBA } \\
\text { Madura } \\
\text { Press } \\
\end{array}$ \\
\hline 3 & Berpulang & Puisi epitaf & $\begin{array}{c}\text { Syair } \\
\text { Nimala }\end{array}$ & $\begin{array}{l}\text { Agung } \\
\text { Purnomo }\end{array}$ & 2019 & $\begin{array}{c}\text { STIEBA } \\
\text { Madura } \\
\text { Press } \\
\end{array}$ \\
\hline 4 & $\begin{array}{c}\text { Bapak } \\
\text { Samsuri } \\
\end{array}$ & $\begin{array}{c}\text { Puisi } \\
\text { Clerihew } \\
\end{array}$ & $\begin{array}{c}\text { Dhalubang } \\
\text { Marta }\end{array}$ & $\begin{array}{l}\text { Agung } \\
\text { Purnomo, } \\
\text { Nur Asitah }\end{array}$ & 2019 & $\begin{array}{c}\text { STIEBA } \\
\text { Madura } \\
\text { Press } \\
\end{array}$ \\
\hline 5 & Dua Kaki & $\begin{array}{c}\text { Puisi } \\
\text { Bebas } \\
\end{array}$ & $\begin{array}{l}\text { Kidung } \\
\text { Nawala } \\
\text { (Jilid 2) }\end{array}$ & $\begin{array}{l}\text { Agung } \\
\text { Purnomo }\end{array}$ & 2018 & $\begin{array}{c}\text { UNUSIDA } \\
\text { Press } \\
\end{array}$ \\
\hline 6 & Tangisnya & $\begin{array}{c}\text { Puisi } \\
\text { Naratif }\end{array}$ & $\begin{array}{c}\text { Bhumi } \\
\text { Bawera }\end{array}$ & $\begin{array}{l}\text { Agung } \\
\text { Purnomo, } \\
\text { Nur Asitah }\end{array}$ & 2019 & $\begin{array}{c}\text { STIEBA } \\
\text { Madura } \\
\text { Press } \\
\end{array}$ \\
\hline 7 & $\begin{array}{l}\text { Sepekan } \\
\text { Awal } \\
\text { Tanpamu }\end{array}$ & $\begin{array}{l}\text { Puisi } \\
\text { bersekuen }\end{array}$ & $\begin{array}{l}\text { Arebhan } \\
\text { Helai }\end{array}$ & $\begin{array}{l}\text { Agung } \\
\text { Purnomo, } \\
\text { Nur Asitah }\end{array}$ & 2019 & $\begin{array}{c}\text { STIEBA } \\
\text { Madura } \\
\text { Press }\end{array}$ \\
\hline 8 & Cantik & $\begin{array}{l}\text { Puisi } \\
\text { Jenaka } \\
\text { Limerick }\end{array}$ & $\begin{array}{l}\text { Lembhar } \\
\text { Jiwana }\end{array}$ & $\begin{array}{l}\text { Agung } \\
\text { Purnomo, } \\
\text { Nur Asitah }\end{array}$ & 2019 & $\begin{array}{c}\text { STIEBA } \\
\text { Madura } \\
\text { Press }\end{array}$ \\
\hline
\end{tabular}




\begin{tabular}{|c|c|c|c|c|c|c|}
\hline 9 & Menyala & $\begin{array}{l}\text { Puisi } \\
\text { Haiku }\end{array}$ & $\begin{array}{l}\text { Tenta } \\
\text { Kimaya }\end{array}$ & $\begin{array}{l}\text { Agung } \\
\text { Purnomo }\end{array}$ & 2019 & $\begin{array}{c}\text { STIEBA } \\
\text { Madura } \\
\text { Press }\end{array}$ \\
\hline 10 & Kita & $\begin{array}{l}\text { Puisi } \\
\text { Bebas }\end{array}$ & $\begin{array}{l}\text { Suweda } \\
\text { Ate }\end{array}$ & $\begin{array}{l}\text { Agung } \\
\text { Purnomo, } \\
\text { Elsa } \\
\text { Rosyidah }\end{array}$ & 2019 & $\begin{array}{c}\text { STIEBA } \\
\text { Madura } \\
\text { Press }\end{array}$ \\
\hline 11 & \#CH1 & $\begin{array}{l}\text { Puisi } \\
\text { Bebas }\end{array}$ & $\begin{array}{l}\text { Kidung } \\
\text { Nawala } \\
\text { (Jilid 1) }\end{array}$ & $\begin{array}{l}\text { Agung } \\
\text { Purnomo }\end{array}$ & 2018 & $\begin{array}{c}\text { UNUSIDA } \\
\text { Press }\end{array}$ \\
\hline
\end{tabular}

\section{KAJIAN SYAIR}

Berikut beberapa syair gubahan Agung Purnomo yakni: rindu di ubun-ubun (Purnomo, 2019c), sepekan awal tanpamu (Purnomo \& Asitah, 2019d), \#CH1 (Purnomo, 2018a), cantik (Purnomo \& Asitah, 2019b), berpulang (Purnomo, 2019a), dua kaki (Purnomo, 2018b), bapak Samsuri (Purnomo \& Asitah, 2019a), menyala (Purnomo, 2019b), tangisnya (Purnomo \& Asitah, 2019e), pandai (Purnomo \& Asitah, 2019c), dan kita (Purnomo \& Rosyidah, 2019).

Setidaknya Agung Purnomo telah berkarya dalam sebelas puisi dengan gaya epitaf, clerihew, bebas, riddle, bersekuen, jenaka limerik dan haiku. Puisi diterbikan pada periode tahun 2018 dan tahun 2019. Sangat direkomendasikan untuk membaca karya-karya puisi beliau. 


\section{REFERENCES}

Conceptodefinicion. (2019). Definición de Poesía.

Retrieved June 27, 2019, from

https://conceptodefinicion.de/poesia/

Hess, G. R. (2019). Poetry Definition - A True

Description and Explanation. Retrieved June 29, 2019, from

https://www.poemofquotes.com/articles/poetry_ definition.php

Literary Terms. (2019). Poetry. Retrieved June 25,

2019, from https://literaryterms.net/poetry/

Purnomo, A. (2018a). \#CH1. In Kidung Nawala (Jilid

1). Sidoarjo: UNUSIDA Press.

Purnomo, A. (2018b). Dua Kaki. In Kidung Nawala

(Jilid 2). Sidoarjo: UNUSIDA Press.

Purnomo, A. (2019a). Berpulang. In Syair Nimala.

Sumenep: STIEBA Madura Press.

Purnomo, A. (2019b). Menyala. In Tenta Kimaya.

Sumenep: STIEBA Madura Press.

Purnomo, A. (2019c). Rindu di Ubun-Ubun. In

Rassana Jlantir. Sumenep: STIEBA Madura

Press.

Purnomo, A., \& Asitah, N. (2019a). Bapak Samsuri.

In Dhalubang Marta. Sumenep: STIEBA

Madura Press.

Purnomo, A., \& Asitah, N. (2019b). Cantik. In

Lembhar Jiwana. Sumenep: STIEBA Madura

Press.

Purnomo, A., \& Asitah, N. (2019c). Pandai. In

Tolesan Aditi. Sumenep: STIEBA Madura Press. 
Purnomo, A., \& Asitah, N. (2019d). Sepekan Awal Tanpamu. In Arebhan Helai. Sumenep: STIEBA Madura Press.

Purnomo, A., \& Asitah, N. (2019e). Tangisnya. In Bhumi Bawera. Sumenep: STIEBA Madura Press.

Purnomo, A., \& Rosyidah, E. (2019). Kita. In Suweda Ate. Sumenep: STIEBA Madura Press. 